Ueber den elektrisehen Widerstand der fetten u. flïchtigen Oele. 105

\title{
Ueber den elektrischen Widerstand der fetten und flüchtigen 0ele.
}

Von Brice-Warren.

Rousseau hat schon vor einigen Jahren die Beobachtung gemacht, dass Olivenöl im Durchschnitt die Elektricitït 675mal schwächer leitet, als alle andern bekannten fetten Oele vegetabilischen und animalischen Ursprungs. Zwei Tropfen Mohnöl, zehn Grammen Olivenöl kinzugefügt, machen die in den Strom eingeschaltete Magnetnadel viermal empfindlicher. Warren hat nun verschiedene Oele, fette wie flïchtige, auf ihre Leitungsfähigkeit für Elektricität, oder, was dasselbe ist, auf den Widerstand, welchen sie einem Strome von gleicher Stärke unter denselben Umständen darbieten, geprüft, wobei sich Differenzen heraustellten, die es gestatten, eine Vermischung des einen Oels mit dem andern zu constatiren und also Fälsehungen nachzuweisen. Die flüchtigen Oele sind im Allgemeinen viel bessere Elektricitätsleiter, als die fetten. Verfälschungen derselben geschehen meistentheils mit Terpenthinöl und Alkohol. Ersteres leistet der Elektricität einen verhältnissmässig ungeheueren Widerstand, letzterer hingegen leitet viel besser, als irgend eines der bekanntern ätherischen Oele; demnach lassen sich grade Zusätze dieser Art mit Leichtigkeit erkennen. (Pharmac. Journ. and Transact. Octbr. 1867 Sec. Sér. Vol. IX. Nr. IV. F. 177 ff.).

$W p$.

\section{Ueber die Leuchtkraft der Flamme.}

\section{Von Frankland.}

Man hat die Leuchtkraft der Flammen des Steinkohlengases bisher davon abgeleitet, dass eine gewisse Menge Kohlenstoff ausgeschieden und inmitten der Flamme durch deren hohe Temperatur zum Glïhen gebracht werde. Verschiedene Umstände scheinen diese Erklärung zu bestätigen. Bringt man z. B. in eine solche Flamme eine kalte Porcellanplatte, so beschlaggt sie mit einem schwarzen kohligen Körper; hält man ein Drahtnetz darüber, so entsteht ein kohliger- Rauch; streut man mittelst eines Siebes in eine bekanntlich sehr schwach leuchtende Wasserstofflamme Kohlenstaub, so wird dadurch die Helligkeit derselben bedeutend erhöht. Hiernach glaubte man das Leuchten einer Flamme von den in ihr suspendirten glühenden festen Partikelchen mit Recht ableiten zu dürfen. 